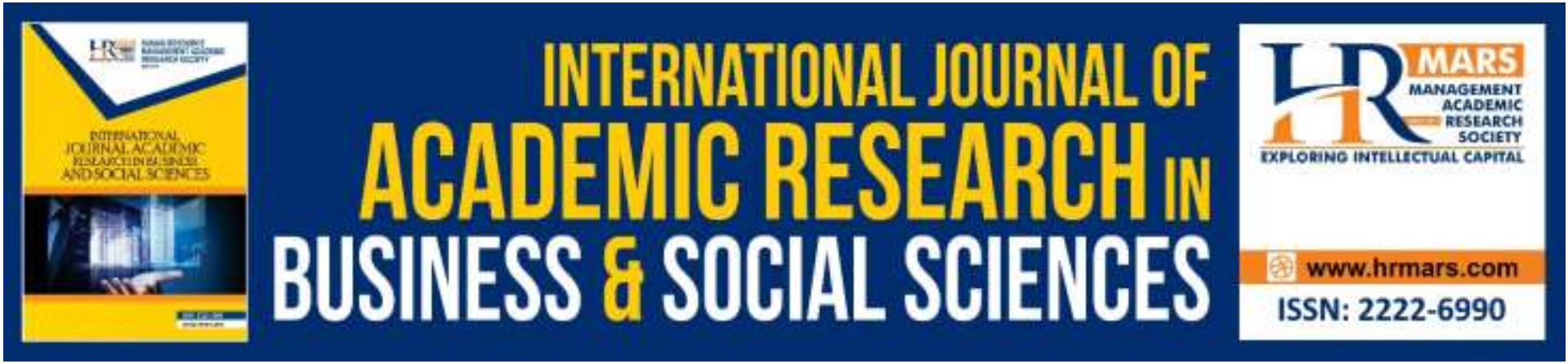

\title{
Paradox of Women Empowerment: The Representations of Women in Television Dramas in Pakistan
}

\author{
Shumaila Ahmed, Juliana Abdul Wahab
}

To Link this Article: http://dx.doi.org/10.6007/IJARBSS/v9-i10/6443

DOI: 10.6007/IJARBSS/v9-i10/6443

Received: 10 August 2019, Revised: 26 August 2019, Accepted: 03 Oct 2019

Published Online: 27 Oct 2019

In-Text Citation: (Ahmed \& Wahab, 2019)

To Cite this Article: Ahmed, S., \& Wahab, J. A. (2019). Paradox of Women Empowerment: The Representations of Women in Television Dramas in Pakistan. International Journal of Academic Research in Business and Social Sciences, 9(10), 1-21.

Copyright: (C) 2019 The Author(s)

Published by Human Resource Management Academic Research Society (www.hrmars.com)

This article is published under the Creative Commons Attribution (CC BY 4.0) license. Anyone may reproduce, distribute, translate and create derivative works of this article (for both commercial and non-commercial purposes), subject to full attribution to the original publication and authors. The full terms of this license may be seen at: http://creativecommons.org/licences/by/4.0/legalcode

Vol. 9, No. 10, 2019, Pg. 1 - 21

http://hrmars.com/index.php/pages/detail/IJARBSS

JOURNAL HOMEPAGE

Full Terms \& Conditions of access and use can be found at http://hrmars.com/index.php/pages/detail/publication-ethics 


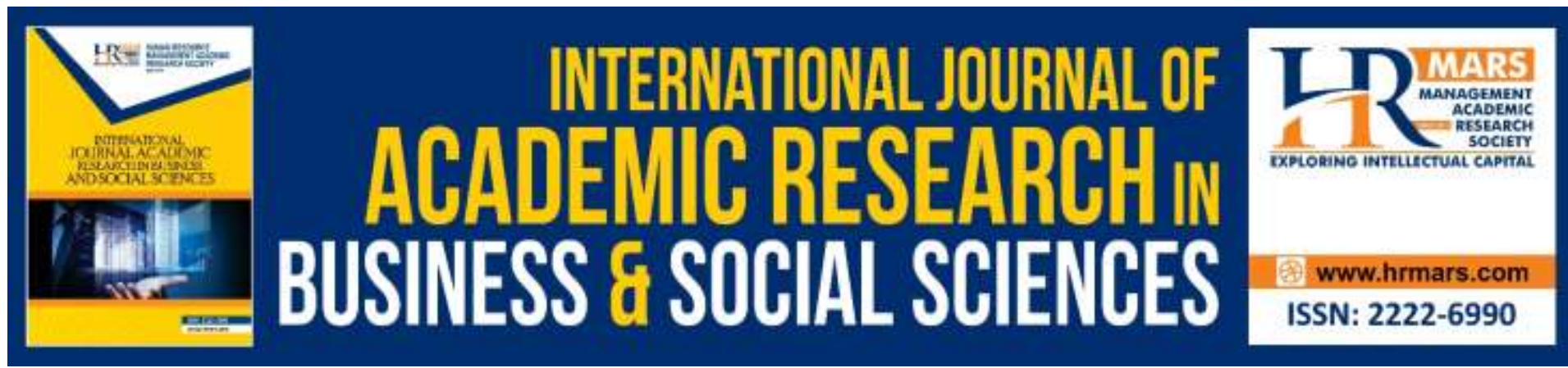

\title{
Paradox of Women Empowerment: The Representations of Women in Television Dramas in Pakistan
}

\author{
Shumaila Ahmed \\ Islamia University of Bahawalpur, Pakistan \\ Email: sanoosh26@yahoo.com.au \\ Juliana Abdul Wahab \\ Universiti Sains Malaysia \\ Email: julia@usm.my
}

\begin{abstract}
This study explored the representation of women in comparison to male characters using a content analysis of 54 episodes of two Pakistani television network dramas. The objective was to observe the representation of major characters, social roles and the issues of violation of women's rights. Under feminist theoretical framework, the findings revealed that women were represented in submissive social roles, exploited under the ideology of patriarchy. Ironically, a political regime, which projects itself as an emancipator and a conscientious feminist, was used to highlight the issues of violation of women's rights. Women empowerment and women's rights' programmes and policies of the ruling elites were used to advance the interests of government and political leaders to sustain control. The study concludes that as an influencer of behaviours and attitudes, patriarchal ideology plays a significant role in the representation of women as weak and submissive in television dramas in Pakistan.
\end{abstract}

Keywords: Drama Television, Content Analysis, Women Empowerment, Violation, Women's Rights, Patriarchy.

\section{Introduction}

Media and especially television is considered influential in its roles in perpetuating dominant ideologies such as patriarchy which can be a driving force in exploitation ideas about women (Duerst-Lahti, 2002). The dominance of the ruling class and imposition of power through the hegemony of patriarchy in society can be seen as a major factor in sustaining women's position in society. Media, particularly television dramas can encourage the audience to develop mindsets of how women should be seen and regard.

In Pakistan Ali and Gavino (2008) observed that Patriarchy and authority of the economic power of men are one of the primary causes of domestic violence against women 
in Pakistan. Men usually rule in the house, family, and women in patriarchal societies like in Pakistan. Women are a victim of violence, like physical and mental torture, child marriages, sexual harassment, stove and acid burn as identified commonly in many areas of the country (Niaz, 2003). Even though many cases reported about this violence against women but still there are some cases of violence against women which go unreported every year in Pakistan.

There are many issues concerning women as well as certain issues of violence against women, which are important to be highlighted to talk about the violation of women's rights. Women are facing discrimination and violence in different aspects of their life. Violation of women's rights through violence against women is a recognised tool to control the sexuality of women and to exercise gender power relation in patriarchal societies (Babur, 2007; Tarar \& Pulla, 2014). Due to the hegemony of the male domination and patriarchal social construction of economic and social norms, women have always been a victim of genderbased violence (Weiss, 1985; Suleman, 1990). Rashid and Kianai (2012) emphasise that constant projection of a positive image of women and highlighting issues of concern regarding women on television can help shape ideas about the role of women in a positive way and increases awareness of women's issues. The continuous projection of issues concerning women and issues of violation of women's rights can have the psychological impact of subconsciously promoting acceptance in society (Rashid and Kiani, 2012). The principal objectives of this study are to analyse the representation of women and to examine the representation of issues of violation of women's rights in television dramas, broadcasted during the ruling regimes of Ms. Benazir Bhutto, the first and only female prime minister in the political history of Pakistan.

\section{Statement of the Problem}

In the Islamic Republic of Pakistan, women have proven themselves to be competent and skilled through their active participation in fields such as the army, media, science, and technology. Some have earned international awards for their significant contributions to the positive portrayal of Pakistani women. Nevertheless, the dominant male ruling class has targeted women as a subordinate class through different means and policies during various ruling political regimes. Ruling political governments in Pakistan have been unstable due to corruption charges against the rulers. To stabilise their governments, the political ruling classes exert hegemony and control over other classes through different policies, programs, or dominant ideologies.

The ideology of patriarchy, which defines women's position in society as subordinate to that of men, has been historically supported and reinforced by not only legal, political, and economic structures, but also the religious system (Dobash \& Dobash, 1979; Weiss, 1985; Eagleton, 1991; Shaheed, 1991; Saigol, 1994; Shah, 1997; Shah, 2012). Hall's (1997) critical approach considers the representation of women in media as the construction of images instead of a reflection of reality, an act of ideological re-creation that controls the media to advance the interests of the dominant class. For their active role in and contributions to society, women should be represented positively in media. However, in television dramas, which are considered the most popular genre of media in Pakistan as well as in Asia (Suleman, 1990), the images constructed of them in society and fields of life are not positive. Studies exploring the representation of women (Suleman, 1990; Shaheed, 1991; Kothari, 1997; Zia, 2007; Mugal, 2011) have demonstrated that due to the patriarchy and a biased political and 
social environment, it is challenging to find an adequate representation of women in television dramas in Pakistan.

Due to the influential and active role of the media, constructed images of women in television dramas can cultivate a negative impression of women in a society, thereby weakening their role and position (Amanda, 2010). Additionally, issues concerning the widespread exploitation of women by the hegemony of the patriarchy have been neglected in media. However, through the proper representation of issues of violation of women's rights, the violence against women can be controlled.

The stereotypical representation of women in constructed images relates to the representation to facilitate ideas about women and women's issues. This research intended to examine the representation of women in the most popular television dramas broadcasted during the ruling regime of Ms. Bhutto in Pakistan by analysing the representation of women and issues of violation of women's rights in television dramas during ruling regimes of Ms. Benazir Bhutto, the first and only female prime minister in the political history of Pakistan.

\section{Theoretical Framework}

\section{Marxist Feminist Theory and Ideology of Patriarchy}

Feminist theory is used as primary idea to study how women represented under the ideology of patriarchy in television dramas during the ruling regimes of Ms. Benazir Bhutto regimes in Pakistan. The ideology of patriarchy in Pakistan is the domination of men in a society or government who hold power and deprive women of their rights (Tarar, 2014). Men are considered dominant by religious, social, and cultural values that prevail through accepted customs and norms in Pakistan.

Feminist theory is based on the importance of rights of women and equality of gender resources and opportunities in every field of society. Murial (1988) emphasises that the way in which women are represented in media was not of concern before feminism and feminist theory. Feminist theory has explained why women and men are treated in different manners in some fields of society (Lorber, 1994). To some extent, feminist theory considers the ideology of patriarchy as the initiator of discrimination and oppression of women in society.

Moreover, feminist theory explores issues or reasons that justify the victimisation of women on the grounds of gender (Verta, Nancy \& Leila, 2009). To some extent, feminist theory identifies patriarchy as the main cause of the imbalance of gender power relations in society. Furthermore, Verta, Nancy, and Leila (2009) argue that women all over the world experience discrimination, violence, and restrictions because they live under the hegemony of male domination in patriarchal societies. Along with gender, differences in class, age, region, and religion are also responsible for women's experiences for instance women living in America have gender discrimination experiences different from those of women living in Asia or Europe. Feminist theory focuses on women, women's rights, women's issues, equality of sex, and problems caused by the patriarchy ideologies and values that subdue women development and achievements in society.

Ideology enters the feminist theoretical framework in explaining how oppressed women take exploitative economic relations for granted as stable and unchangeable. The Marxist theory uses the notion of ideology to describe the process through which the dominant ideas within a given society reflect the interests of a ruling economic class (Kim, 2008). Shaw (1983) stresses that because of these unequal social and economic relations, the 
class with the ability to control and protect the production relations becomes the hegemonic class.

Based on the understanding that unequal social positions lead to social domination, the Marxist feminist theory is a critical theoretical and political framework that aims to understand and explain gender oppression through socioeconomic control in a systematic way (Holmstrom, 2002). The Marxist feminist theory identifies the power or economic class differences as the primary cause of gender discrimination and exploitation of women in different fields of life, including in the home, media, and workplace.

Marxist feminist theory condemns class differences that are constructed in the name of patriarchy and includes discussion of the rights of women (Vogel, 2013). This idea represents not only political and economic power and discrimination but also the ability of the dominant class to project its way of seeing the world so that the subordinate class accepts it as natural.

The Marxist feminist theory claims that women are oppressed by the dominant power structure as a subordinate class (Worsley, 1999). This perspective draws our attention to the issue of political and economic interests of the ruling group in media and highlights social inequalities in the representation of women in media. Vogel (2013) also claims that Marxist feminist theory identifies the ideology of patriarchy as the primary driver of economic exploitation of women by the dominant and powerful class.

According to Lim (1997), the ideology of patriarchy is the system of male domination and female subordination in economy, society, and culture that has characterised much of human history to the present day. Patriarchal institutions and social relations are responsible for the inferior or secondary status of women in society (Duerst-Lahti, 2002). However, because of dominant ideologies of class difference, working classes take their exploitation within an economic structure of inequality for granted (Lim, 1997). Women do not get paid for the duties which they perform at home and are considered domestic servants for men. In all societies in which patriarchy prevails as the dominant ideology, women are regarded as inferior and second-class.

Marxist feminist theory calls for a change in the system of production to eliminate social classes based on the exploitation of one class by another (Kim, 2008). Class differences result in the exploitation of women by the dominant class of men, which holds control under the ideology of patriarchy.

Men monopolise the power and authority in society and distance themselves from women; therefore, male-dominated ruling groups institutionalised discriminatory policies and practices against women to gain acceptance and control on the submissive class of women (William, 1993). Marxist feminist theory aims to define, establish, and defend equal political, social, and economic rights for women. The state and media control the representation of women in society through patriarchy and domination in the official positions as the dominant group (Duerst-Lahti, 2002). As they hold the powerful and authoritative positions, only men can control the subordinate classes. The concept of patriarchy was most notably formed as a form organization where the father dominated the household (Barrett, 2014). According to Barrett (2014), early modern feminist theorists created a concept of patriarchy based on an over-arching category of male dominance. There is a definitional confusion of the concept of patriarchy, as both patriarchy as the rule of the father and patriarchy as the domination of women by men exist (Barrett, 2014). Early radical 
feminists conceptualized patriarchy as a system of domination completely independent of the organization of capitalist relations, which speaks in universalistic, trans-historical modes.

The Marxist feminist theory argues that women are discriminated against through the ideology of patriarchy in a culture or country based on class differences and economic differences (Holmstrom, 2002). The humanist approach to Marxist feminist theory emphasises that as human beings, all men and women are equal and there should be no discrimination based on the class difference. By taking a humanist approach of Marxist feminist theory to evaluate the equal representation of women in media, the discrimination, exploitation, and stereotypical construction of images of women as a submissive class under the hegemony of ruling governments and ideology of patriarchy in Pakistan is analysed.

\section{Marxist Feminist Theory and Representation of Women in Media}

Representation of gender in media supports the institutionalisation of male dominance thus bolstering the hegemony of the male-dominated class. According to Hall (1977), the Marxist approach views the media as a powerful influence on public consciousness through the ideas it transmits. Verta, Nancy, and Leila (2009) argue that media is a contemporary moderator of hegemony; therefore, it constructs its dominant ideology according to the interests and benefits of its owners or those who control its economic position and production. The media is the spokesperson of the groups that feed it. The government or state controls the mass media and what broadcasted through it based on the economic and productive dictates of the dominant class.

Media forms are sites where the ideas of the dominant group prevail and are circulated. The state departments that indirectly own or control media sometimes censor or restrict programs to align with the social policy of supremacy and dominance (Duerst-Lahti, 2002). Thus, the dominant ideology earns the acceptance of ordinary people through control of media.

As a powerful and influential institution, the media represents the world in a way that supports the dominant ideology. Media supports the conventional notion that men are more suitable for positions of power, supremacy, and decision-making, at work and at home (Kim, 2008). In countries where institutions and organisations of mass media are owned and controlled by the ruling class, the media serves the ideological interests of the ruling class. Often, these interests include the state's political objectives to gain the favour of the public through shared interests (Davidson, 1992).

The dominant ideology is projected to the subordinate group through institutions like the media (Coltrane \& Messineo, 2000). The research on the representation of women in media has revealed that around the world, images of women in media tend to reinforce traditional attitudes, dominant social norms and values, and socio-religious structures of societies (Kim, 2008; Shaheed, 1991). With conscious or unconscious effort, the practices of subordinate groups (women) change according to the ideologically painted images of their class.

Feminists insist that women's rights should be equal to those of men. Therefore, women should be granted equal respect and status in society (Kim, 2008). Feminists have also focused on the representation of women in popular media (Shaheed, 1991). The Marxist feminist theory claims that women in every society are represented as victimised and stereotyped due to their subordinate positions based on the class difference (Coltrane \& Messineo, 2000). Another significant trend in media is that specific groups (men) are 
represented as essential and desirable while others are depicted as deviants and troublemakers (women).

Despite the increasing number of women in the labour force, few working women are represented, and of those who are, some are condemned, and others trivialised (Greenwood \& Lippman, 2010). Despite the changes in lives and activities of middle-class, educated women in Pakistan and other developing countries, media continues to represent women as occasional oddities, not as participants in the social change process (Suleman, 1990). Given these representations in the Third World media, it can have argued that this symbolic annihilation of female roles is a tactic for controlling changing perceptions and consciousness about the contribution of women to national economies (Kim, 2008).

The media, as an agent of socialization, is a major tool that can be utilized by the ruling authority (e.g. the patriarchal order) to present depictions of oppression. Analysing media by way of Marxist feminism is important in the present study because it is centred on content analyses of television dramas and representation of women in the selected dramas broadcasted during the political ruling regime of first and only female prime minister of Pakistan.

Studying the representation of gender and specifically, women remain of the utmost importance because watching television still is the most time-consuming pastime (Collins, 2011; Signorielli, 1994). As a result, television dramas are one of the main institutions associated with disseminating stereotyped views of the world and its gender social roles. Now, representation of women in media, especially in television drama, has become an integral part of the media agenda. Women are represented as selling commodities, sexual items, and victims in television dramas and other media.

Hall (1982) takes the representation of women in media as an act of re-creation of the dominant ideology that is meant to control the media for the achievement of specific interests and goals of the dominant ruling class. The stereotypical representation of women in constructed images relates to the representation to facilitate some ideas about women and women issues.

This research intended to examine the representation of women in the most popular television dramas broadcasted during the ruling regime of Ms. Bhutto in Pakistan. The research gap is filled by analysing the representation of women and issues of violation of women's rights in television dramas during ruling regimes of Ms. Benazir Bhutto, the first and only female prime minister in the political history of Pakistan.

\section{Political Regime of Ms Benazir Bhutto (1988-1990; 1993-1996)}

This regime was very important in the political history of Pakistan, a woman, Ms Benazir Bhutto (1988-1990; 1993-1996) became the Prime Minister of Pakistan. She was the first women prime minister of a Muslim country. When elected in 1988, she was identified as a powerful feminist symbol for females in the politics in Muslim countries. Being an active and struggling political leader, she was a high hope for the ordinary people, feminists and especially for the oppressed women community of Pakistan which identified with her programme of feminism (Jafar, 2005; Naz, 2013). After an extended period of the military regime of President Zia-ul-Haq, the regime of Ms Benazir was considered as a source of relief for the women from the unjustified patriarchal restrictions and legislation (Rehman, 2012).

Due to her political struggles, women in Pakistan achieved eligibility to stand for elections in the legislative assemblies to be entitled to the presidency and prime ministership 
(Naz, 2013). Some women-friendly measures during her regime, such as setting up of women studies centres in public universities have helped in the empowerment of women. Furthermore, the first women bank was established which worked to provide small business loans to women to make them financially independent and vigorous. Women police stations were also set up to help and take women complaints of domestic violence and sexual harassment.

Ms Bhutto was criticised by some religious clerics of that time with the claim that a woman could not be a president or prime minister of a Muslim country (Rehman, 2012). At the same time, she tried to reverse the hegemony of male-domination and patriarchy which prevailed during the military regime of President Zia-ul-Haq. Under Ms Bhutto's ruling programme of feminism, the struggles for women's rights and empowerment were identified as a blessing and hope for the suppressed and distressed class of women in Pakistan.

\section{The position of Women in Media}

In the presence of media laws and controlled policies, representation of women in different fields of life, professions as well as in media was encouraged in the country. However, television media remained under the control of government just like the regime of President Zia, but the government of Ms Benazir relaxed the policies regarding media freedom in Pakistan. The government of Ms Benazir Bhutto lifted the restrictions and censorship from the print media, and as a result, there was a remarkable change and revolution in the representation of women in media. Media was free to represent women in different genres such as dramas in a variety of social roles. General atmosphere for women became liberal as compared to the previous regime of President Zia because women were not forced to observe the strict dress code.

At last, many feminist movements achieved their goals and acceptance of equality for women's rights towards men was noticed in different fields of life (Shaheed, 1991). The participation of women in sports and entertainment shows was encouraged during the political regimes of Ms Bhutto. Many female producers and writers joined the media, and a variety of excellent dramas on different social issues were produced. Ms Bhutto's government allowed the television media to broadcast the drama and non-drama programmes on social issues of ordinary people. Consequently, those issues were highlighted in the television drama genre, which affected ordinary people and especially women in the context of the patriarchal society in Pakistan.

\section{Women's Rights and Women Empowerment}

Ms Benazir Bhutto was considered as an outspoken defender of women's rights and feminism in Pakistan which recognized her ruling regime with a programme of feminism (Saigol, 1994). In 2008, Benazir Bhutto was included in the list of seven winners from United Nation's prize for working on women's rights. As being the first female Prime Minister of the country, it was a conventional thinking in women's community as well as in women's organisations that all the previous crucial laws against women would be revised and revealed.

However, due to the hegemony of the ideology of patriarchy and male domination at the Parliament level, Benazir could not implement any affirmative feminist policy in the country (Rehman, 2012). All her regime's efforts went in vain because of considerable criticism from some religious groups and male-dominated political parties (Saigol, 1994). The main criticism of religious group was that a woman could not be a ruler of a Muslim country. 
To some extent, this government and its women prime minister had to face many difficulties in the amendment of the laws which implemented through the hegemony of patriarchy against women (Jafar, 2005). As a result of all this opposition, Benazir remained unsuccessful in eliminating all the discriminatory laws from the constitution of Pakistan.

On the other hand, one of her considerable efforts was to establish a separate ministry for women in the country. In the year 1993, Pakistan signed the Vienna Declaration for recognition of women's rights as human rights. During the second period of Benazir Bhutto's ruling regime as prime minister in 1994, the government of Pakistan established a highpowered commission to work for equal rights for women. That commission gave some recommendations for the equality of duties on human rights basis. In United Nation's fourth international conference on women's rights in 1995 in Beijing, Ms Benazir represented Pakistan.

At the national level, civil society groups worked in collaboration with the government on national report for Beijing in 1995, to highlight different forms of violence against women and recommended measures. In 1996, it was followed by government-run shelter homes for women who faced domestic violence. National Plan of Action (1996) for women was also a part of the implementation of Beijing platform for women's rights. The primary focus of the Beijing Conference was to increase the participation of women in decision-making to promote an unbiased and non-stereotypical representation of women in media. Although Ms Benazir Bhutto signed the declaration of this conference, despite all that, the media remained under the government control to work under the censorship of public policy.

On the other hand, despite all these struggles and Benazir's feminist approach, any revolutionary change in the situation of women empowerment was not identified in the country. The main reason was the presence of the hegemony of ideology of patriarchy of dominant class over the subordinate social class of women (Saigol, 1994). Ms Bhutto was unable to change all those laws which were established in the name of Islamization through the ideology of patriarchy and the male domination for the exploitation of women as a submissive class.

\section{Major Issues of Violation of Women's Rights in Pakistan}

There are many issues concerning women as well as certain issues of violence against women, which are important to be highlighted to talk about the violation of women's rights. Women are facing discrimination and violence in different aspects of their life. Violation of women's rights through violence against women is a recognised tool to control the sexuality of women and to exercise gender power relation in patriarchal societies (Babur, 2007; Tarar \& Pulla, 2014). Due to the hegemony of the male domination and patriarchal social construction of economic and social norms, women have always been a victim of genderbased violence (Weiss, 1985; Suleman, 1990). Some of the key issues and violence practices which women are facing in Pakistan are discussed as follows.

\section{Child Marriage / Underage Marriage}

More than 2000 girls forcefully compelled to marriage every year, before the registered age for marriage of 18 years (Amnesty International, 2014). These kinds of underage marriages are widespread in rural areas of Pakistan as well as in other parts of South Asia (Niaz, 2003). The underage marriages are not just the violation of the act of humanity 
themselves but are also recognized as a dangerous kind of sexual violence against the girls of young age which sometimes recognised as a reason of high death rate of young women.

\section{Honour Killing}

According to the latest survey report of Human Rights Commission of Pakistan 2012, about more than 1000 girls are killed or murdered every year by their close relatives or family members, father, brother or husband in the name of honour. In most of the cases, the honour killing justifies the murder under this note that accused women is engaged in immoral behaviour, which is intolerable in Islam and in an Islamic state like Pakistan (Tarar \& Pulla, 2014). According to the report of Amnesty International, 2010, thousands of women are killed every year in the name of so-called "honour killing" in Pakistan.

Karo-Kari is also a common tradition to kill women under the charge of adultery if she wants to get married to a man of her own choice (Mumtaz \& Shaheed, 1987; Griffin, 1996; Shah, 1997). Honour killing in Sindh province in Pakistan is named as Karo Kari, while it is popular as Kala Kali in the province of Punjab. Similarly, in Khyber Pakhtunkhwa, it is famous as TorTora and at the same time as Siyahkari in Balochistan. All these terms are used in Pakistan for those persons who are accused of indulging in immoral or morally wrong activities.

Traditionally, honour killing in Pakistan identifies as murder (Babur, 2007). Honour killing is accepted and recognised as a way of protecting family honour and a private matter of the household (Satar, 2015). Members of a certain tribe or a family consciously decide to kill an allegedly adulterous guilty individual and the perpetrators are backed by their families.

\section{Rape/ Sexual Violence}

Sexual abuse / Rape is the most common kind of crimes all over the world as well as in Pakistan. Moreover, Pakistan includes in the list of those countries, where the ratio of sexual harassment and gang rape is rising gradually (Satar, 2015). Particularly during the last ten years, the incidents of gang rape have increased very rapidly. According to the report of Human Rights Commission of Pakistan, 2014, one woman is raped in the country in every two hours, however, many cases are remained unreported because of the shame attached to the victim.

According to the Human Rights Commission of Pakistan (HRCP, 2014), about 597 women were gang-raped, and 823 women were raped or had faced sexual violence, during the year 2014. Sexual harassment is also widespread in homes as well as in workplaces due to the dominance of men which identify ideology of patriarchy as one of the causes of sexual violence against women (Brock-Utne, 1989; Asif, 2011). In most of the cases, the women are harassed by some of their family member or some very close relative.

\section{Trafficking of Women}

Trafficking and smuggling of women, from Pakistan to other countries and from Afghanistan to Pakistan is also very high. According to the report of the Human Rights Commission of Pakistan (2014), about 2400 cases are reported for the kidnapping of women in Pakistan. These kidnapped women are later used for prostitution and trafficking across the borders of the country. 


\section{Marriage with Quran}

Marriage with Quran or Haq-Baksh-wai is also a crucial tradition, which has no basis in Islam. However, in the last 50 years, it is playing a role in violence against women. Some young girls are forced for marriage to the Holy Quran, by some feudalist families, to keep their property within the family (Shah, 1997). The male members of these families could go to any extreme to prevent women from violating the old traditions of this kind. According to the latest report by an NGO (Aurat Foundation, 2012), there are currently over 5000 women in Pakistan, who are still living as a victim of this tradition.

\section{Forced Prostitution}

Forced Prostitution is also very common in poor families in Pakistan. Many girls are forcefully pushed or indulged in the profession of prostitution to support their family financially. According to Brock-Utne (1989) in a society where the rule of patriarchy prevails, many women of low-income families are sometimes compelled by their spouse or close family member to earn money through prostitution.

\section{Acid Attacks}

During the last few decades, this violent criminal activity has increased in the country. Many countries like Cambodia, India, and Bangladesh are identified high in this list (Niaz, 2003). Pakistan is among those high-risk countries where young girls get attacked by acid throwing on their faces. Most of the cases of acid throwing are found in the tribal areas of the country where customs of covering woman face is very strict in the region (Hassan, 1995). Likewise, many women are victimised through this violent act by other men for blame of bad conduct or for dishonouring them in the society.

According to the statistics of "Aurat Foundation" (2014) about 579 cases of acid attacks are reported during the year 2013. However, reasons range from marriage proposal rejection to religious fundamentalism. Due to this violence against women, sometimes either they die, or their sight or face is damaged severely.

\section{Vani/Swara (Women Trade)}

It is a widespread customary practice, to sell or exchange women for settling family disputes. Many girls in different rural areas of Pakistan are sold or exchanged by some rival family or group to relax some contentious issue of males of the family. Young girls and women are given or paid to the rival families, in the compensation of the crime of some men of that family (Babur, 2007; Hassan, 1995). These are a kind of forced marriages of women to the men of some rival group, even in some cases there is a mismatch of the age of that girl and man.

Many times, girls of very young age are pushed forcefully to get married to a man of the older age of some rival group, just to settle the dispute of male members of the rival families (Niaz, 2003). This custom is called Vani in Punjab and is known as Swara in the areas of Khyber Pakhtunkhwa of Pakistan. Women are sold and bought as an item or commodity instead of taken as a human being. Selling of women to exchange marriages is also widespread in many rural parts of the country. 
Table: Reported cases of violence against women in Pakistan in 2017.

Violent issues $\quad$ Reported cases

\begin{tabular}{ll}
\hline Murder & 1575 \\
\hline Rape/Sexual violence & 827 \\
\hline Domestic Violence & 610 \\
\hline Honour killing & 705 \\
\hline Acid Attacks & 44
\end{tabular}

Source: Amnesty International Report 2017. The state of the world's Human Rights.

Additionally, house burns, physical torture, many fatal diseases like breast cancer, HIV Aids, and high death rate at childbirth or during pregnancy are also some of the leading issues that concern women's rights, which should be addressed in media. Different governments have passed some Acts and Ordinances, but there is no proper implication of any law, regarding women in Pakistan. Various commitments at the national and international level are made to ensure gender equality, but there is always a wide gap between commitments and implementations. Violence and discrimination seem more prominent in South Asian countries, like Malaysia, Indonesia, Bangladesh, Nepal and Pakistan (Niaz, 2003). It is the need of the time to represent a positive image of a woman in television media to fight against the violence and discrimination against women in the world.

In this age of media, it is the responsibility of television media to play its active role to highlight the issues concerning women, instead of representing women in constructed stereotypical social roles and behavioural traits. A survey conducted in 2011 by United Nations Development Program (UNDP) on "Representation of women in media" indicates that the viewers' preferences are now tilting in favour of more gender-balanced representation of women on the central issues of the women all over the world. The respondents of the survey feel that the stereotypical images of highly emotional and suppressed women should be reduced and downplayed.

The revolution is required in the thinking pattern of the male members to change the existing notion of power and the male domination. The requirement in the present scenario is not to empower one gender over the other but a balance between the two genders towards the achievement of joint goals, better society and better future for the upcoming generations by being proud of one's own culture.

\section{Representation of Women and Women Issues in Pakistan}

Due to the cultural hegemony of the male domination and patriarchal social construction of economic and social norms, women have always been a victim of genderbased violence (Weiss, 1985; Suleman, 1990). Surveys of most of NGO's like "Aurat Foundation" and "Aks Foundation" have proved that about $80 \%$ of women in the country were victims of some violence. In the presence of gender discrimination, violence against women was recognised as a serious and problematic issue all over the world (Tarique, 2008). Some surveys at domestic level suggest that domestic violence against women has been observed in about 80 per cent, from slapping to being murdered brutally (Niaz, 2003). In the 
perspective of Pakistan, women used to face violence as well as male domination from the dominant class.

Women in Pakistan could be unfortunate, because of being a victim of traditional narrow-mindedness and the male domination which prevails in all areas of the country. Not only the conventional and cultural values but also the misinterpretation of religious norms is also one of the most significant hurdles in the progress and development of women (Weiss, 1985). During the last many years, different political regimes have used the tool of manipulation of Islam to oppress women in all the major fields of life. Due to the religious and social norms of patriarchy, women must depend socially and financially on men and they could not have economic freedom (Shaheed, 1991). This economic dependence is one of the reasons, due to which women do not have opportunities and rights equal to men.

Patriarchy and authority of the economic power of men are one of the primary causes of domestic violence against women in Pakistan (Ali \& Gavino, 2008). Men usually rule in the house, family, and women in patriarchal societies like in Pakistan. Women are a victim of violence, like physical and mental torture, child marriages, sexual harassment, stove and acid burn as identified commonly in many areas of the country (Niaz, 2003). Even though many cases reported about this violence against women but still there are some cases of violence against women which go unreported every year in Pakistan.

Ms Benazir Bhutto was the first women prime minister, among all the Muslim countries. Ms Bhutto has been identified as a powerful feminist symbol for female community in the politics of Muslim countries (Saigol, 1994). In United Nation's fourth world conference in 1995, she represented Pakistan and has always raised her voice for the rights of women in the world. A separate women ministry was also established in the country to work for the rights of women. Many feminist reforms came during this regime and women gained equality of rights and equality of representation in media (Shaheed, 2009). Media was free to represent women in different kinds of programmes and television dramas. Many women producers and directors joined the television industry, and a variety of dramas on women issues were broadcasted during her regime.

\section{Research Methodology}

The methodology employed in this study is content analysis. The data for the study was collected from the content of television dramas and was analysed using two approaches of content analysis. Quantitative approach was used to examine the distribution of male and female characters in the main protagonist and antagonist roles, to document characters' social roles whilst the qualitative analysis was done to examine the representation of women in different social roles, and characters.

Data from the study is significant because the television drama serials selected for the analysis were produced and telecasted during the ruling regimes in which the status and role of Pakistani women were influenced by the programmes and policies of the ruling class. Given this historical and political context, it is also known that television tends to present preferred meanings and interpretations of the cultural values that support the dominant ruling class (Hall, 1997). The representation of women is controlled by the conventional socio-religious value system and actions of the ruling class, in contrast to modern and broad-minded approaches in different regimes. Representation establishes the process through which the meaning of an image or ideology is constructed through media content as codes (Hall, 1997). To explain the relation between content analysis and meaning, Gramsci (1977) stressed that 
hegemony's power in a society was enhanced because of the way representations are transmitted by media content as codes loaded with cultural meanings that condition us to think ways. Gramsci's (1977) point was that we have been conditioned by codes to think and feel through some cultural perspective in a manner that serves the dominant ideology. Stuart Hall's (1997) approach supported ideological beliefs and cultural trends by identifying specific images concerning the representation of gender and different classes. The content analysis helped yield the findings regarding the dominant ideology such as the ideology of patriarchy.

The most commonly used sampling method in research is purposive sampling (Creswell, 2007). Through the purposive sampling approach, the researcher selected only samples with common features or characteristics that could be helpful for exploring the research objectives (Ritchie \& Lewis, 2003). Thus, for this study, the researcher selected the most popular dramas with women as leading characters in the storyline. During the first regime, only two dramas met this criterion, so to maintain the pattern, the two most popular dramas were selected from each political ruling regime.

The drama series were analysed using a mix of quantitative and qualitative methods. The quantitative approach examined the distribution of male and female characters and their roles (i.e. protagonist or antagonist), characters' physical appearances, and behavioural traits or attributes. Qualitative analysis examined the different social roles, behavioural traits and characters of women in the representation. The physical appearance and objectification were analysed to examine the representation of women as objects of the male gaze in the selected television dramas.

Only those dramas were selected which had highlighted the issues of violation of women's rights through their plot and storyline. Every drama serial consisted of 26 episodes. A total of 54 episodes of 54 hours' duration of selected dramas were analysed. The names of selected dramas were Nijaat (Freedom, 1991) and Marvi (A Brave Girl, 1993) from the selected ruling regime.

\section{Data Analysis and Findings}

\section{Representation of Women in Drama Serial Nijaat (Freedom, 1991)}

The drama serial Nijaat (Freedom) was produced and broadcasted in 1993 from the national and government-owned and government-controlled channel of television in Pakistan, which was Pakistan Television Network (PTV). A famous male drama writer, Asghar Nadeem Syed wrote this drama, which was produced and directed by Sahira Kazimi, a feminist producer, and director in Pakistan. Saira has been famous for producing television drama serials on women issues and problems in the society. She represented the problems and struggles of women in urban and rural areas of different social classes. In this selected drama, Saira represented the women of three different families, as struggling for their identification and rights in the system of patriarchy in the male-dominated society of Pakistan.

This selected television drama was a famous feminist serial in the history of Pakistan's television drama. The drama serial Nijaat achieved many media and critic awards as a successful family drama in Pakistan (PTV library). Many issues like family planning, women health issues (because of consecutive pregnancies), child marriages, and un-matched exchange marriages (Watta-Satta), child trafficking and child labour were highlighted in this selected television drama. 


\section{Representation of Women in Drama serial Marvi (A brave girl, 1993)}

From the ruling period of Ms Benazir Bhutto (1988-1991, 1993-1996) the second selected drama serial was Marvi (A brave girl,1993). The drama serial Marvi was produced and broadcasted in 1993 by Pakistan Television Network (PTV) national and governmentowned and government-controlled channel of television in Pakistan. PTV ruled the Pakistani audience from 1968 to 1991 as the only television channel in the country. This drama was included in the category of classic drama which was a modern version of Sindhi folk tale. This drama serial was broadcasted during the ruling regime of the first female prime minister of the country whose political government ruled the country with an aim to promote the feminist policies by focusing on the equality of rights for women in the country.

Marvi was written by a famous female feminist drama writer, Noor-ul-Huda Shah and produced by Sultana Siddiqui (the first woman owner of a television channel in the country and was famous for producing drama serials on social issues and problems of women). Sultana Siddiqui has represented the women, independent and confident enough to fight for their rights in the male-dominant society. However, in a few dramas, Sultana represented women somewhat stereotypically, by recognising them as less powerful than their male counterparts. This selected drama had achieved many media critic awards as a successful classic drama in Pakistan.

\section{Representation of Women in Characters and Characterization}

Marvi had a total of 4 characters, with $75 \%(n=3)$ identified as females (three protagonists $100 \%, 0$ antagonist $0 \%)$ and $25 \%(n=1)$ identified as male (0 protagonist $0 \%, 1$ antagonists $100 \%$ ), while $75 \%(n=3)$ were identified as protagonist characters ( 3 females $100 \%$ ), and $25 \%(n=1)$ were identified as antagonist characters ( 0 females $0 \%, 1$ male $100 \%$ ). Nijaat had a total of three characters coded, with $67 \%(n=7)$ identified as females (two protagonists $100 \%, 0$ antagonists $0 \%$ ) and $33 \%(n=1)$ identified as males (0 protagonist $0 \%$ and one antagonist $100 \%)$, while $75 \%(n=2)$ were identified as protagonists characters (2 females $100 \%)$, and $25 \%(n=1)$ were identified as antagonist character ( 0 female $0 \%, 1 \mathrm{male}$ $100 \%)$.

This study identified that female characters outnumbered by male characters in the main protagonist and antagonist roles. The findings revealed that male characters often represented as antagonists. However, female characters were rarely represented in antagonists' roles. Female characters were often represented in protagonist characters as beautiful, sexual, caring and loving, sacrificing, submissive.

\section{Representation of Women in Social Roles}

The representation of women in main characters as protagonists and antagonists was analysed in this study. For a better picture of representation of women in selected television dramas, the representation of women in different social roles was analysed. In drama Nijaat, Sajida was interpreted stereotypically in submissive social role as a weak woman who forcefully compelled by her dominant husband to give birth to a child after every year. The second female protagonist character was Zareena; she was represented non-stereotypically as a strong woman, who dared to talk against patriarchy and used to work outside the home to support her family. Similarly, she represented non-stereotypically with a short haircut and very simple attires without any makeup. The short haircut identified her as a stand against the social norms of patriarchy. 
All the main protagonist and antagonist male characters which were selected to be analysed in Marvi represented in dominant social roles, and they always tried to suppress women because women accounted for in the social roles as weak and submissive towards male characters. In a feminine notion, in the selected drama Marvi, women were represented in stereotypical social roles in relationship with men and identified as sacrificing daughter, weak sister and submissive wife. However, in the drama serial, Nijaat, women in main protagonist characters were represented non-stereotypically as strong enough to counter patriarchy.

\section{Representation of Issues of Violation of Women's Rights}

Many issues concerning women as well as certain issues of violence against women, which were identified as important to be analysed in the study of the selected dramas ruling regimes in Pakistan. Due to the male domination and patriarchal social construction of economic and social norms, women have been victimised and exploited through patriarchy. The issues concerning women, violation of women's rights and issues of gender-based violence were important to be presented through the plot and theme of the television dramas. For the second objective of the study, the data was analysed to examine that to what extent and how the issues of violation of women's rights were highlighted in the selected dramas across the different ruling regimes. It was important because the governments during these ruling regimes targeted and controlled the women through political programmes and policies. The representation of issues of violation of rights of women such as child marriage, women trafficking, domestic violence and honour killing, was studied and analysed.

Many issues of violation of women's rights were highlighted and discussed in the selected drama Nijaat. It was the only selected drama which was broadcasted during the political regime of Ms Benazir Bhutto, that represented most of the issues concerning women. The data analysis identified a positive representation of issues of violation of women's rights through some common issues of violence against women in Pakistan. The plot of the drama Nijaat was based on the issues of child marriage, exchange marriage, domestic violence, sexual harassment and women health issues.

One of the issues of violence against women was the custom of child marriage and exchange marriages in Pakistan which has exploited the rights of many young women. More than 2000 girls forcefully compelled to marriage every year, before the registered age for marriage of 18 years (Amnesty International, 2014). These kinds of underage marriages are widespread in rural areas of Pakistan as well as in other parts of South Asia (Niaz, 2003). The drama highlighted that male member of the family force the young girls in exchange for marriage with old men just for their personal interests and desires. The drama recognised the critical issues of child labour and women health issues due to frequent pregnancies in the plot of the story. The main protagonist characters were represented as strong to fight against the violence of male-dominated class and patriarchy. The analysis revealed that the recognition of such issues and their solution in the television dramas could help to protect women's rights.

The issue of honour killing or Karo-Kari (a cultural tradition in the Sindh province to murder a girl by accusing her of adultery) was highlighted in the drama Marvi. In most of the cases, the honour killing justifies the murder under this note that accused women is engaged in immoral behaviour, which is intolerable in Islam and in an Islamic state like Pakistan (Tarar \& Pulla, 2014; Satar, 2015). According to the report of Amnesty International, 2010, 
thousands of women are killed every year in the name of so-called "honour killing" in Pakistan.

Karo-Kari (honour killing) is also a common tradition to kill women under the charge of adultery if she wants to get married to a man of her own choice (Mumtaz \& Shaheed, 1987; Griffin, 1996; Shah, 1997). The analysis of the representation of the issue of honour killing has revealed that women victimised and murdered due to the domination of patriarchy. It represented that on the name of honour killing, men used to kill women brutally without any substantial reason or justification. However, the main protagonist character of Marvi was represented strong as she raised her voice against the violence against women. The drama highlighted that women should be educated to fight against their rights. Forced marriages of women without their consent, another issue which was represented in this drama. The analysis revealed that the issue of forced marriage was not highlighted in a powerful way which identified the presence of patriarchy in the decision of marriage of women in Pakistan.

\section{Women Empowerment under Benazir's Feminist Regime}

The content analysis revealed that the women empowerment was tried to be achieved through stable and equal representation of women to that of men, during the political regime of Prime Minister Ms Benazir Bhutto. The issues of women's rights violations and violence against women discussed in the selected drama serials of the regime of $\mathrm{Ms}$ Benazir Bhutto, who ruled the country through her feminist policies and claimed to protect the rights of women in the country. The sufferings and different issues of violence against women were highlighted through these dramas in storyline and characterization. Benazir's era is the only political regime during which many issues of violation of women's rights were represented with powerful effects and storylines. Issues such as child marriage, Watta Satta (exchange marriages), child labour, Karo Kari (honour killing), and many others contributed to solid storylines of the dramas broadcasted during this ruling regime. Similarly, the dramas highlighted that how the health of women is affected by unwanted and frequent pregnancies and abortions every year in the country.

These dramas also represented the women as equally supportive to their families, financially as well as morally. Women can be equally helpful and supportive of men in their family by participating equally to solve household problems, and they are strong enough to challenge male domination. To a certain extent, the selected television dramas had empowerment elements reflected through the dominant images of women as strong-willed and fighting to stand by their own beliefs and values. This study also found that women's social class, job status, level of education, and character traits are more positively depicted than before.

Although the selected dramas represented the women as an exploited class under the ideology of patriarchy, their images were constructed as healthy women fighting against their victimisation to protect their rights. Women were represented as strong, even when they belonged to the weak group but may be allowed in the dominant ruling group, so long as they support the ideology of patriarchy. One example is of Prime Minister Benazir Bhutto herself, who supported the policies and male domination during the ruling period of her regime.

Ms Bhutto, as a woman, represents an oppressed and subordinate class of society. However, her use and abuse of her political power to oppress the masses reinforced feudal and patriarchal practices exercised by her male predecessors as well as her successors since her removal from power. Although identified as a class of equal status and empowerment at 
some points, women are also represented as exploited through the ideology of patriarchy in the selected television dramas.

\section{Conclusion}

The study of all the ruling political regimes and analysis of selected dramas identified that all the different political ruling governments established their hegemony as a dominant class through some ideology to obtain control of the submissive classes in the country. The ruling governments used programmes or policies as tools to achieve hegemony and domination over the submissive class of the society. It could be said that the power and dominance of the ruling class relates to the social conflict that arises due to the hegemony of the ideology of patriarchy in society as well as in media.

It is concluded after a brief study that women are often represented as confined to their homes, with pleasing their father, husband, or brother in the social role as daughter, wife, or sister as the primary purpose of their lives. These constructed images of women confirm the aim of the state or ruling dominant class to limit the genuine and respectable place of a woman to serve her men or family at home. Such representation portrays women as submissive objects of beauty that provide services for the sexual satisfaction of the male gaze and the happiness of men. This constructed representation of women results from the exploitation of women by men and strengthens the ideology of patriarchy in society.

Although the construction of protagonist female characters is showing some positive orientations, the supporting female roles in selected dramas still have negative orientations that do not improve the overall image of women. This calls for gender-sensitized content producers and writers alongside women-friendly policies and laws by the ruling governments in Pakistan. If the media can shape and structure people's perceptions of discriminating social roles and values, the same institution can give a more dynamic and real image of women as human beings with their own rights.

Arguably, all media, television included, is responsible to play its active role to highlight issues concerning women. When it some to presenting women, media should focus to improve that images and issues about women were presented. Instead of portraying women in stereotypical manners, media should play an active role to promote positive images and highlight issues that is significant in bringing changes in women's life. A Survey conducted in 2017 by United Nations Development Program (UNDP) on "Representation of women in media" indicates that the viewers' preferences are now tilting in favour of more genderbalanced representation of women on the central issues of the women all over the world. The respondents of the survey feel that the stereotypical images of highly emotional and suppressed women should be reduced and downplayed.

The revolution is required in the thinking pattern of the male members to change the existing notion of power and the male domination. The requirement in the present scenario is not to empower one gender over the other but a balance between the two genders towards the achievement of joint goals, better society and better future for the upcoming generations by being proud of one's own culture. Media content, especially television dramas that represent women and women's issues, need a reorientation. Television dramas should be more future-oriented, rational, highly informative, educational, and inspiring so that they can empower women by highlighting the issues of women's rights violations. There should be a serious reconsideration of the content of television dramas, to highlight the constructive image of women in society. 
The media is a powerful tool for education, social change, and awareness of issues of women's rights violations. It has the capacity to preserve, record, and define human culture and history. Nevertheless, due to insensitivities on the part of content or producers, it tends to project stereotypical generalizations of women.

Additionally, it is recommended that issues concerning the violation of women's rights should be highlighted in the plots of television dramas. Raising awareness of issues that cause a violation of women's rights and violence against women in Pakistan should be a goal of representation of women in television dramas. To achieve women empowerment, women's struggles and their place in society should be represented in a positively constructed manner.

\section{References}

Ali, P. A., Gavino, M. I. B. (2008). Violence against Women in Pakistan A Framework for Analysis. Journal of Pakistan Medical Association, 58, 198-203.

Amanda, D. (2010). Redesigning Women: Television after the Network Era. University of Illinois Press. USA.

Babur, Z. U. (2007). Violence against Women in Pakistan: Current realities and strategies for change. Retrieved April 10, 2013, from http://www.epu.ac.at/epu/research/Babur.pdf.

Collins, R. L. (2011). Content analysis of gender roles in media: Where are we now and where should we go? Sex Roles, 64, 290-298.

Coltrane, S., Messineo, M. (2000). The Perpetuation of Subtle Prejudice: Race and Gender Imagery in 1990's Television Advertising. Gender Roles, 42(5/6).

Creswell, J. (2007). Qualitative inquiry and research design: Choosing among the five Traditions $\left(2^{\text {nd }}\right.$ ed). Newbury Park: Sage Publications.

Davidson, A. (1992). Antonio Gramsci. In P. Belharz (ed) Social Theory: A Guide to Central Thinkers. Sydney: Allen \& Unwin

Disch, E. (2003). Reconstructing Gender. A Multicultural Anthology. Boston, MA: McGraw Hill. Dobash, R. E., Dobash, R. (1979). Violence Against Wives. New York: The Free Press.

Duerst-Lahti, G. (2002). Governing Institutions, Ideologies and Gender Political Representation. Sex Roles, 47(7/8).

Eagleton, T. (1991). Ideology: An Introduction. Verso Publications. London. New York.

Greenwood, D. N., Lippman, J.R. (2010). Gender and Media: Content, Uses and Impact. Handbook of Gender Research in Psychology. Springer New York

Griffen, J. (1996). Women Murdered without a second Thought. Dawn Publishers.

Hall, S. (1997). Representation: Cultural Representations and Signifying Practices. Thousand Oaks, London.

Hall, S. (1982). The Rediscovery of Ideology: the return of the repressed in media studies. In Gurevitch et al. (ed), Culture, Society and Media, New York.

Jafar, A. (2005). Women, Islam and the State in Pakistan. Gender Issue. 22(1), 35-55.

Kothari, S. (1997). From Genre to Zanana: Women and Urdu drama serials in Pakistan. PhD Dissertation, University of Texas, 1997.

Kim, S. (2008). Feminist Discourse and the Hegemonic Role of Mass Media. Newspaper Discourse about two South Korean Television Dramas. Feminist Media Studies, 8(4). Doi: 1080/14680770802420303. 
Lim, L. Y. (1997). Capitalism, Imperialism, and Patriarchy: The dilemma of third world women workers in multinational factories. The Women Gender and Development Reader. The University Press Limited Dhaka. London Zed Books.

Mughal, S. (2011). The Fate of Tomorrow in the Hands of Women: Gender, Social Position and the Media during Zia-ul-Haq's Campaign. (Honors Thesis), The University of New Jersey.

Mumtaz, K., Shaheed, F. (1991). Women of Pakistan: One Step Forward, Two Steps Back? Lahore: Vanguard Publishers.

Murial, C. G. (1988). Feminism and the Media, Arts and Media. Feminist Publishing House. London.

Naz, A., Hussain, M., Daraz, U., Khan, W., Khan, T., Salman, M., \& Khan, M. A. (2013) A Paradigm shift in Women's Movement and Gender Reforms in Pakistan. (A Historical Overview). Global Journal of Human Social Science. Sociology and Culture, 13 (1).

Niaz, U. (2003). Violence against Women in South Asian countries. Journal of Arch of Women Mental Health, 6(3).

Rashid, M. M., Kiani, A. (2012). An Exploratory Study of Projection of Positive Image of Women through Media. Academic Research International, 2(2).

Rehman, B. H. (2012). The framing of Pakistani Muslim Women in International Media: Muslim Feminist Perspective. American International Journal of Contemporary Research, 2 (1).

Ritchie, J., Lewis, J. (2003). Qualitative Research Practice: A Guide for Social Science Students and Researchers. Thousand Oaks, CA: Sage.

Saigol, R. (1994). Women Islamization and Justice. In K Bhasan, R. Memon and N. S. Khan (eds). Against all the odds: Essays on Women, Religion and development. New Delhi India. Isis International.

Satar, A. (2015). The Laws of Honour Killing and Rape in Pakistan: Current Status and Future Prospects. AWAZ publishing program.

Shaheed, F. (1991). The Cultural Articulation of Patriarchy. Lahore. Pakistan: ASR Publications.

Shaheed, F. (2009). The Women's Movement in Pakistan: Challenges and Achievements. Lahore: Vanguard Publishers

Shah, J. (2012) Zia-ul-Haq and the Proliferation of Religion in Pakistan. International Journal of Business and Social Science, 3(21).

Shaw, W. H. (1983). Historical Materialism. In T. Bottomore, L. Harris (V.G. Kierman \& R. Miliband (Ed). A dictionary of Marxist Thought. Cambridge, M.A: Harvard University Press.

Suleman, S. (1990). Representation of Gender in Prime-time Television: A Textual Analysis of Drama Series of Pakistani Television. PhD Thesis. The University of WisconsinMadison. The USA.

Tarar, M. G., Pulla, V. (2014). Patriarchy, Gender Violence and Poverty amongst Pakistani Women: A Social Work Inquiry. International Journal of Social Work and Human Services Practice, 2 (2).

Verta, T., Nancy, W., Leila, R. J. (2009). Feminist Frontiers. McGraw-Hill Publishers. The USA.

Vogel, L. (2013). Marxism and the Oppression of Women: Toward a Unitary Theory. Rutgers University Press. The United States of America.

Weiss, A. M. (1985). Women's Position in Pakistan: Sociocultural Effects of Islamization. Asian Survey, $25,(8)$. 
Williams, C. L. (1993). Psychoanalysis and the Sociology of Gender/Feminism on Theory, edited by P. England. Hawthorne. NY: Aldine de Gruyter.

Zia, A. (2007). Media and Gender: Pakistani Perspective. AMIC Conference. Singapore.

Zia, A. S. (2009). The Reinvention of Feminism in Pakistan. Feminist Review, 91(1). 